\title{
IMPACT OF CREDIT RATINGS ON STOCK RETURNS
}

\author{
Krishna Reddy ${ }^{1}$, Rudi Bosman², Nawazish Mirza ${ }^{3}$ \\ ${ }^{1}$ Postgraduate Business, Toi Ohomai Institute of Technology, Rotorua, New Zealand. \\ Email: krishna.reddy@xtra.ac.nz \\ ${ }^{2}$ Waikato Institute of Technology, Hamilton, New Zealand. Email: rudi.bosman@wintec.ac.nz \\ ${ }^{3}$ La Rochelle Business School - Excelia Group, La Rochelle, France. Email: nawazish.mirza@spjain.org
}

\begin{abstract}
This study investigates whether a change in credit ratings lead to a change in daily excess stock returns. The sample includes daily stock price data for US firms listed on the Standard \& Poor's 500 from January 2006 to December 2015. Firms' excess stock returns are compared with the market in a 14-day window around credit rating downgrades and upgrades. Our results are asymmetric, that is, there is a significant reaction to credit ratings downgrades but not to upgrades. In addition, we report weak evidence of upgrades in credit ratings since the 2008 global credit crisis leading to significant changes in security prices.
\end{abstract}

Keywords: Credit ratings; Firms; Stock returns; Global financial crisis.

JEL Classifications: G01; G14.

Article history:

Received : August 1, 2018

Revised : December 2, 2018

Accepted : December 17, 2018

Available online : January 30, 2019

https://doi.org/10.21098/bemp.v21i3.986 


\section{INTRODUCTION}

Credit ratings measure an entity's creditworthiness. ${ }^{4}$ Credit ratings provide forward-looking estimations regarding credit risk and thus provide opinions on the relative ability of an entity to meet financial obligations. ${ }^{5}$ Credit rating agencies such as Standard \& Poor's (S\&P), Moody's, and Fitch provide credit rating information that allows investors to evaluate the financial health and credit worthiness of a firm. Credit rating agencies claim that their opinions are based on inside information that is unavailable to stock analysts (He, Wang, and Wei, 2011). Investors are influenced by credit ratings when deciding the securities in which they want to invest (Avramov, Chordia, Jostova, and Philipov, 2009).

However, credit ratings are only opinions and not recommendations to buy, sell, or hold a security (Gonzalez, et al., 2004; Erlenmaier, 2011; Nordberg, 2011. High ratings are not a guarantee that an entity is a safe investment. Even an entity with an AAA rating (the highest) has approximately one chance in 600 of default over a five-year period. The differences in credit quality increase with each category lower down the scale, which is reflected in the default frequencies measured of the individual categories (Matthies, 2013). For example, over an 18-year period, from 1971 to 1988, there were no one-year defaults in the AAA or AA category (Zhou, 2001). Table 1 summarizes the credit rating scales used by the three largest credit rating agencies, that is, S\&P, Moody's, and Fitch.

Table 1.

Summary of the Rating Scales

The table shows a summary of the rating scales used by the three big rating agencies, namely, Standard \& Poor's, Moody's and Fitch.

\begin{tabular}{|c|c|c|c|c|c|}
\hline & Description & $\begin{array}{l}\text { S\&P } \\
\text { Scale }\end{array}$ & $\begin{array}{l}\text { Moody's } \\
\text { Scale }\end{array}$ & $\begin{array}{l}\text { Fitch } \\
\text { Scale }\end{array}$ & $\begin{array}{c}\text { Approx. probability } \\
\text { of default over } 5 \\
\text { years* }\end{array}$ \\
\hline & \multicolumn{5}{|l|}{ Investment Grade } \\
\hline \multirow{10}{*}{ 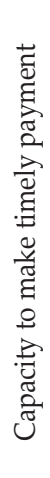 } & Extremely Strong & AAA & Aaa & AAA & 1 in 600 \\
\hline & Very Strong & $\mathrm{AA}+$ & Aa1 & $\mathrm{AA}+$ & 1 in 300 \\
\hline & & $\mathrm{AA}$ & Aa2 & $\mathrm{AA}$ & \\
\hline & & AA- & Aa3 & AA- & \\
\hline & Strong & A+ & $\mathrm{A} 1$ & A+ & 1 in 150 \\
\hline & & A & A2 & A & \\
\hline & & A- & $\mathrm{A} 3$ & A- & \\
\hline & Adequate & $\mathrm{BBB}+$ & Baa1 & $\mathrm{BBB}+$ & 1 in 30 \\
\hline & & BBB & Baa2 & BВB & \\
\hline & & BBB- & Baa3 & BBB- & \\
\hline
\end{tabular}

4 For the purpose of this study, the term entity refers to the issuer of bonds and other securities.

5 Examples of financial obligations are loan repayments (principal), interest, preferred dividends, and insurance claims. 
Table 1.

Summary of the Rating Scales (Continued)

\begin{tabular}{|c|c|c|c|c|c|}
\hline & Description & $\begin{array}{l}\text { S\&P } \\
\text { Scale }\end{array}$ & $\begin{array}{l}\text { Moody's } \\
\text { Scale }\end{array}$ & $\begin{array}{l}\text { Fitch } \\
\text { Scale }\end{array}$ & $\begin{array}{c}\text { Approx. probability } \\
\text { of default over } 5 \\
\text { years* }\end{array}$ \\
\hline & \multicolumn{5}{|l|}{ Speculative Grade } \\
\hline \multirow{12}{*}{ 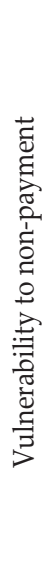 } & Less Vulnerable & $\mathrm{BB}+$ & Ba1 & $\mathrm{BB}+$ & 1 in 10 \\
\hline & & BB & $\mathrm{Ba} 2$ & BB & \\
\hline & & BB- & $\mathrm{Ba} 3$ & BB- & \\
\hline & More Vulnerable & $\mathrm{B}+$ & B1 & $\mathrm{B}+$ & 1 in 5 \\
\hline & & B & B2 & B & \\
\hline & & B- & B3 & B- & \\
\hline & Currently Vulnerable & $\mathrm{CCC}+$ & Caa1 & $\mathrm{CCC}+$ & 1 in 2 \\
\hline & & $\mathrm{CCC}$ & $\mathrm{Caa} 2$ & $\mathrm{CCC}$ & \\
\hline & & CCC- & $\mathrm{Caa} 3$ & CCC- & \\
\hline & Currently Highly Vulnerable & $\mathrm{CC}$ & & $\mathrm{CC}$ & \\
\hline & Default & $\mathrm{D}$ & $\mathrm{Ca}$ & DDD & \\
\hline & & & C & $\mathrm{DD}$ & \\
\hline
\end{tabular}

The literature reports that changes in credit ratings have different effects on stock returns (Bissoondoyal-Bheenick and Brooks, 2015). Early studies, using monthly stock and bond returns, find no evidence that bond and stock prices respond to changes in bond ratings (Weinstein, 1977; Pinches and Singleton, 1978). In contrast, recent studies document the price relevance of credit ratings. They use common (daily) stock prices to examine responses to bond rating changes (Poornima et al., 2015; Kenjegaliev et al., 2016). Their results show that bond downgrades by rating agencies are associated with negative abnormal stock returns, but there is little evidence of abnormal stock performance being associated with upgrade announcements. While changes in credit ratings have both bond and stock price effects, capital market responses mainly tend to be asymmetric with respect to credit rating changes (Choy et al., 2006; May, 2010; Freitas and Minardi, 2013; Fatnassi et al., 2014; Poornima et al., 2015; Mokoaleli-Mokoteli and Mongalo, 2017). Other studies mainly confirm that announcements of upgrades over different categories have no significant impact on security prices (Choy et al., 2006; Halek and Eckles, 2010; Freitas and Minardi, 2013).

Mokoaleli-Mokoteli and Mongalo (2017) measure the abnormal returns of firms listed on the Johannesburg Stock Exchange that underwent a rating change between 2000 and 2015. The authors report no significant impact of credit rating upgrades announced by the rating agencies on equity prices; however, the market reacted significantly negatively to the announcements of firms' credit rating downgrades. The negative reaction to downgrades suggests that only credit rating downgrades contain relevant pricing information. 
The differences in market reactions to rating upgrades and downgrades can be explained by the discretionary disclosure hypothesis, that is, where managers have discretion over the disclosure of information and prefer to announce good news straight away while allowing bad news to be released more slowly (Chen et al., 2001; Bae et al., 2006; Alsakka and Gwilym, 2012). Therefore, good news is linked with greater disclosure and reduced information asymmetry. On the other hand, bad news is associated with reduced disclosure and greater information asymmetry (He et al., 2011).

A major anomaly is reported by Kenjegaliev et al. (2016) analysing the impact of credit rating changes using German stock data. They show that the German stock market adjusts stock prices long before the rating change announcements are made. Moreover, they report that the market reacts more strongly to downgrades than to upgrades.

Some researchers argue that firms associated with higher credit ratings are viewed as a lower-risk investment and vice versa. On the other hand, empirical research provides evidence that $s$ strong positive correlation between higher credit ratings and firm returns. In other words, low rated firms have lower returns regardless of the level of the risk that investors hold (Bissoondoyal-Bheenick and Brooks, 2015; Narayan et al., 2017).

Researchers investigating the effect of change in the US firm credit ratings (Holthausen and Leftwich, 1986; Dichev and Piotroski, 2001; Brune and Liu, 2010; Halek and Eckles, 2010; May, 2010; Galil and Soffer, 2011; He et al., 2011), European (Gärtner, Griesbach, and Jung, 2011; Urguiza, Navarro, and Trombetta, 2012; Bernoth, Von Hagen, and Schuknecht, 2012; Fatnassi, Ftiti, and Hasnaoui, 2014; Kenjegaliev, Duygun, and Mamedshakhova, 2016), and Australasian (Choy, Gray and Ragunathan,2006; Creighton, Gower, and Richards, 2007; Li, Jeon, and Chiang, 2008; El-Shagi, 2010; Bissoondoyal-Bheenick and Brooks, 2015; Poornima, Umesh, and Reddy, 2015) markets report mixed results, which suggests that the debate is not over and further investigation is required. Furthermore, there are only scant studies on whether current and potential investors have taken greater note of changes in credit ratings during or after the financial crisis period of 2008.

Since the US was highly affected by the global financial crisis (GFC), we examine how credit rating change announcements impact S\&P500 firms' stock prices from January 2006 to December 2015. We are interested in determining whether there is information content in credit ratings for current and potential investors in the securities market and whether they lead to significant changes in stock prices after announcements of changes (up or down) to firm credit ratings. We undertake further analysis to determine whether the market reacts more strongly to one of the three credit rating agencies S\&P, Moody's, and Fitch. Furthermore, this study analyses whether the impact of ratings changes over or within different classes of ratings, that is, investment versus speculative.

To minimize the impact of other information released at the same time as credit rating announcements, this study uses daily stock returns to evaluate the responsiveness of returns to such announcements. We also control for the impact of outliers, which can lead to spurious results.

The main finding of this study is that credit ratings, on average, are negatively correlated with future default rates. For example, a firm with the highest credit rating of AAA is less likely to default in the future compared to one with a credit 
rating of B. Furthermore, we report mixed results over the different periods tested. Tests for the whole sample produced asymmetric results, similar to prior studies (e.g. Choy et al., 2006; May, 2010; Freitas and Minardi, 2013; Fatnassi et al., 2014; Poornima et al., 2015). A credit rating downgrade leads to a significant market reaction, whereas an upward change in credit ratings has no significant impact on the prices of securities.

\section{DATA}

Our sample includes firms listed on the S\&P 500 index from January 2006 to December 2015. Data for security prices are from DataStream. Daily share prices are used and prices are adjusted for stock splits and dividends. Any firm with less than 10 years of data is omitted. Our final sample includes 449 firms (see Table 2, Panel A). The Thomson One database was used to extract information on the credit ratings of firms. The credit ratings for each company over the 10-year period were closely examined to determine if any upward or downward adjustments were made and 1,427 cases were noted. Included in this sample are 68 changes in the credit ratings of companies where a change from one rating agency was followed by a change in credit rating from another agency within five days. This study ignores these second changes in credit ratings. A period of five days was selected as the event window, which will range in this study from three days prior to the event (i.e. the credit rating change) to 10 days after the change. This is to ensure that only a single change in credit rating is analysed for a firm. Studies that use longer time periods also exclude the impact of second rating change observations (He et al., 2011; Choy et al., 2016). After all the exclusions and deletions, we obtain a final sample of 1,359 observations, or rating change events, that is, 702 upward changes and 675 downward changes.

To analyse how the GFC impacted stock prices, the sample is divided into three subperiods: January 2006 to December 2007 (pre-GFC), January 2008 to December 2008 (GFC), and January 2009 to December 2015 (post-GFC). Table 2 reports the results for the subperiods as follows: from January 2006 to December 2007, there were 172 credit rating upgrades and 128 downgrades; during the credit crisis year 2008, there were only 60 credit rating upgrades and 120 downgrades; and from January 2009 to December 2015, there were 470 credit rating upgrades and 409 downgrades (see Panel A).

The sample is further partitioned into credit rating agency-specific observations to test the impact of rating change announcements by the different rating agencies, namely, Fitch, Moody's, and S\&P. Table 2, Panel B, shows that the rating changes by S\&P over the observed period outweigh those by Fitch and Moody's. Based on the final sample of 1,359 rating observations, 804 (59.2\%) were announced by S\&P, compared to $386(28.4 \%)$ by Fitch and 169 (12.4\%) by Moody's.

Additional analysis was undertaken to evaluate the effect of changes in credit ratings within and between different rating classes. These movements of changes are categorized as movements within investment-grade credit ratings, movements within speculative-grade credit ratings, movements up from speculative- to investment-grade credit ratings, and movements down from investment- to speculative-grade credit ratings. Table 2, Panel C, show most credit rating changes 
(961 of 1,359 , or $70.7 \%$ ) occur in the investment-grade range. The low numbers of observations where credit ratings changed up from speculative to investment grade $(85$, or $6.3 \%)$ or down from investment to speculative grade $(49$, or $3.6 \%)$ are a big disappointment.

Table 2.

Description of the Sample

The table shows a description of the sample. Panel A provides a summary of the overall changes in the credit ratings observed during the sample period and in subsample periods. Panel B provides a summary relating to the changes in the credit ratings announced by each rating agency. Panel $\mathrm{C}$ provides a summary relating to the changes in the ratings announced for different class securities.

\begin{tabular}{lccc}
\hline Panel A - Overall Changes in Credit Ratings Observed & & & \\
\hline Sample & Upgrades & Downgrades & Total \\
\hline Total Rating Changes & & & 1,427 \\
Total Final Sample: Jan 2006 - Dec 2015 & 702 & 657 & 1,359 \\
Sample: Jan 2006 - Dec 2007 & 172 & 128 & 300 \\
Sample: Jan 2008 - Dec 2008 & 60 & 120 & 180 \\
Sample: Jan 2009 - Sep 2015 & 470 & 409 & 879 \\
\hline
\end{tabular}

Panel B - Changes in Credit Ratings by Rating Agency

\begin{tabular}{lccc}
\hline Observations of Rating Changes by S\&P & Upgrades & Downgrades & Total \\
\hline Total Final Sample: Jan 2006 - Dec 2015 & 441 & 363 & 804 \\
Sample: Jan 2006 - Dec 2007 & 95 & 72 & 167 \\
Sample: Jan 2008 - Dec 2008 & 44 & 68 & 112 \\
Sample: Jan 2009 - Sep 2015 & 302 & 223 & 525 \\
\hline Observations of Rating Changes by Fitch & Upgrades & Downgrades & Total \\
\hline Total Final Sample: Jan 2006 - Dec 2015 & 199 & 187 & 386 \\
Sample: Jan 2006 - Dec 2007 & 62 & 38 & 100 \\
Sample: Jan 2008 - Dec 2008 & 13 & 35 & 48 \\
Sample: Jan 2009 - Sep 2015 & 124 & 114 & 238 \\
\hline Observations of Rating Changes by Moody's & Upgrades & Downgrades & Total \\
\hline Total Final Sample: Jan 2006 - Dec 2015 & 62 & 107 & 169 \\
Sample: Jan 2006 - Dec 2007 & 15 & 18 & 33 \\
Sample: Jan 2008 - Dec 2008 & 3 & 17 & 20 \\
Sample: Jan 2009 - Sep 2015 & 44 & 72 & 116 \\
\hline Panel C - Changes in Credit Ratings by Class of Rating & & \\
\hline Observations of Rating Changes within and Between Rating Classes & \\
\hline & Upgrades & Downgrades & Total \\
\hline Total Sample & 702 & 657 & 1,359 \\
Changes within Investment Grade Class & 449 & 512 & 961 \\
Changes up from Speculative to Investment Grade & 85 & & 85 \\
Changes down from Investment to Speculative Grade & 168 & 96 & 264 \\
Changes within Speculative Grade Class & \multicolumn{3}{|c}{} \\
\hline
\end{tabular}


Table 2.

Description of the Sample (Continued)

\begin{tabular}{lccc}
\hline Observations of Changes between 2006-2007 & Upgrades & Downgrades & Total \\
\hline Total Sample & 172 & 128 & 300 \\
Changes within Investment Grade Class & 120 & 91 & 211 \\
Changes up from Speculative to Investment Grade & 14 & & 14 \\
Changes down from Investment to Speculative Grade & & 14 & 14 \\
Changes within Speculative Grade Class & 38 & 23 & 61 \\
\hline Observations of Rating Changes in 2008 & Upgrades & Downgrades & Total \\
\hline Total Sample & 60 & 120 & 180 \\
Changes within Investment Grade Class & 32 & 81 & 113 \\
Changes up from Speculative to Investment Grade & 8 & & 8 \\
Changes down from Investment to Speculative Grade & & 11 & 11 \\
Changes within Speculative Grade Class & 20 & 28 & 48 \\
\hline Observations of Changes between 2009-2015 & Upgrades & Downgrades & Total \\
\hline Total Sample & 470 & 409 & 879 \\
Changes within Investment Grade Class & 297 & 340 & 637 \\
Changes up from Speculative to Investment Grade & 63 & & 63 \\
Changes down from Investment to Speculative Grade & & 24 & 24 \\
Changes within Speculative Grade Class & 110 & 45 & 155 \\
\hline
\end{tabular}

\section{METHOD}

The majority of the literature has used event study methods and daily return data to measure reactions to rating change announcements (Hand et al., 1992; Choy et al., 2006; Li et al., 2008; Galil and Soffer, 2011). These studies consider the rating announcement day as day 0 and measure returns for various windows (from day -120 to +90; Galil and Soffer, 2011) and from six months to three years after the event (Dichev and Piotroski, 2001). One of the shortcomings of these studies is their inability to evaluate the reactions to these events in isolation from all pertinent information that the market has access to during the date of the announcement. For example, some rating announcements are accompanied by one or more concurrent disclosures that could have influenced the results. Therefore, other research has claimed that the ideal window for event studies of this nature is 11 days long, from days $T-5$ to $T+5$ or days $T-3$ to $T+10$ (Corwin and Lipson, 2000; Kryzanowski and Nemiroff, 2001; Choy et al., 2006; Brune and Liu, 2010). Moreover, checks should be made to ensure that no contaminated data are used; that is, any news/stories not released by the rating agency itself but related to the observation in question on the days surrounding the rating announcement should be ignored (Holthausen and Leftwich, 1986; Choy et al., 2006). To overcome the limitation stated above, this study uses a relatively short window of 11 days to analyse the data. 
Another issue faced by prior researchers is the impact of outliers on the results. For example, Kim, Kim, and Ergun (2015) remove the top two outliers on opposite sides of the distribution and conclude that the distortions outliers cause can be large. Galai, Kedar-Levy, and Schreiber (2008) note that a relatively small number of daily return outliers, namely, $2.03 \%$ of the sample, severely affects the empirical estimation. To control for the effect of outliers, any observations of a credit rating change announcement accompanied by other news or events related to the company are excluded. This ensures that any abnormal returns recorded on bonds and/or stocks can only be related to the announcement of a rating change for that company. Furthermore, we undertake robustness checks by removing first $1 \%$ and then $2 \%$ of the observations, in line with the method of $\mathrm{Ng}$ and McAleer (2004), Galai et al. (2008), and Kim et al. (2015).

Event study method is common to evaluate the type of research question we have, and we use this method. Daily data are used to measure expected and abnormal returns. We use daily log returns because these are convenient for multiperiod returns (Campbel, Lo, and MacKinlay, 1996), a better median is derived when forecasting future cumulative returns (Hughson, Stutzer, and Yung, 2006), and the use of the logarithms of returns avoids negative security prices in security return models (Jorion, 2001). As stated above, a suitable event window to test how credit rating changes impact security prices is 11 days (Corwin and Lipson, 2000; Kryzanowski and Nemiroff, 2001; Choy et al., 2006; Brune and Liu, 2010 ), that is, from day $\mathrm{T}-3$ to day $\mathrm{T}+10$. Event windows $\mathrm{T}-1$ to $\mathrm{T}+1$ and $\mathrm{T}-3$ to $\mathrm{T}+3$ are used for robustness checks.

Abnormal returns $\left(A R_{i t}\right)$ are measured using the market-adjusted return model, which allows one to capture the price effect of a firm's stock due to changes in credit rating (MacKinlay, 1997). Daily log returns $\left(r_{i t}\right)$ are calculated as follows:

$$
r_{i t}=\ln \left(\frac{P_{i t}}{P_{i t-1}}\right)
$$

The expected or normal returns for each entity are estimated using a market model. The alpha and beta are calculated using the regression model based on the S\&P 500 as the comparative market:

$$
r_{i t}=\alpha_{i}+\beta_{i} r_{m t}+e_{i t}
$$

Next we compute the abnormal returns $\left(A R_{i t}\right)$ for each company on day $t$ :

$$
A R_{i t}=r_{i t}-\widehat{\alpha}_{i}-\widehat{\beta}_{i} r_{m t}
$$

The $A R$ are calculated to determine if returns are significantly different from expected returns after there is a change in ratings. A standard paired $t$-test is undertaken to determine whether the differences between the abnormal returns observed and expected returns are statistically significant. 
To evaluate if investors react more strongly to changes in the credit ratings of firms before or after the global crisis period, $t$-tests are undertaken. Tests are run to determine the statistical significance of the difference between abnormal returns observed over the event windows and expected returns over the twoyear period before the GFC, and the results are compared with those for the year associated with the crisis and six years after the crisis. The results are significant, thus suggesting that investors are taking more notice of changes in credit ratings after the GFC compared to before it. For robustness checks, the test is run for the three different event windows for each period.

\section{RESULTS}

Table 3, Panel A, contains results for the differences in means for the credit rating upgrades for the different windows. Panel B contains results for the differences in means for the credit rating downgrades for the same period and event windows. Results corroborate those documented in the literature. The results for 2006 to 2015 considered over a 14-day window $(\mathrm{T}-3$ to $\mathrm{T}+10)$ for the downgrades and upgrades are asymmetric. Panel B shows that downgrades in credit ratings lead to significant changes in security prices. These results are confirmed when we analyse the data for the event windows $\mathrm{T}-1$ to $\mathrm{T}+1$ and $\mathrm{T}-3$ to $\mathrm{T}+3$.

Regardless of the windows considered, the $t$-values exceed the $t$-critical value, indicating that there are indeed significant changes to returns on securities in response to downgrades of credit ratings. The $p$-values for the three event windows for downgrades also confirm that the changes are significant. Because the $p$-value $<0.05$ ( $\mathrm{T}-3$ to $\mathrm{T}+10, p=0.006$; $\mathrm{T}-3$ to $\mathrm{T}+3, p=0.015 ; \mathrm{T}-1$ to $\mathrm{T}+1, p=0.004$ ), the probability of the changes being due to chance is low, meaning that credit rating downgrades significantly affect returns.

Table 3.

T-Tests for Differences in Mean for Credit Ratings

The table shows the $t$-tests for differences in mean for credit ratings. Panel A reports the $t$-test statistics for the differences in mean for the credit rating upgrades for the event windows T-1 to T+1, T-3 to T+3, and T-3 to T+10 for the years 2006 to 2015. Panel B reports the $t$-test statistics for the differences in mean for the credit rating downgrades for the event windows $\mathrm{T}-1$ to $\mathrm{T}+1, \mathrm{~T}-3$ to $\mathrm{T}+3$, and T-3 to T+10 for the years 2006 to 2015. The variance in Panel B is multiplied by 1000.

\begin{tabular}{lcccccc}
\hline Panel A & \multicolumn{7}{c}{$\begin{array}{c}\text { Event Window: T-1 } \\
\text { to T+1 }\end{array}$} & $\begin{array}{c}\text { Event Window: T-3 } \\
\text { to T*3 }\end{array}$ & \multicolumn{2}{c}{$\begin{array}{c}\text { Event Window: T-3 } \\
\text { to T+10 }\end{array}$} \\
\hline & Variable 1 & Variable 2 & Variable 1 & Variable 2 & Variable 1 & Variable 2 \\
\hline Mean & -0.0005 & 0.0013 & 0.0005 & -0.0009 & 0.0022 & -0.0004 \\
Variance & $1.86 \mathrm{E}-05$ & 0.0004 & 0.0005 & 0.0012 & 0.0001 & 0.0038 \\
Observations & 702 & 702 & 702 & 702 & 702 & 702 \\
Pearson Correlation & 0.5901 & & -0.085 & & 0.5601 & \\
Hypothesized Mean & 0 & & 0 & & 0 & \\
Difference & & & & & 701 & \\
df & 701 & & 701 & & 1.2188 & \\
$t-$-Stat & -2.638 & & 0.8693 & & 0.2233 & \\
P(T<=t) two-tail & 0.0085 & 0.385 & & 1.9633 & \\
$t$ Critical two-tail & 1.9634 & & 1.9634 & &
\end{tabular}


Table 3.

$T$-Tests for Differences in Mean for Credit Ratings (Continued)

\begin{tabular}{|c|c|c|c|c|c|c|}
\hline \multicolumn{7}{|l|}{ Panel B } \\
\hline \multirow[t]{2}{*}{ Down-grade in credit rating } & \multicolumn{2}{|c|}{$\begin{array}{l}\text { Event Window: } \mathrm{T}-1 \\
\text { to } \mathrm{T}+1\end{array}$} & \multicolumn{2}{|c|}{$\begin{array}{l}\text { Event Window: } \mathrm{T}-3 \\
\text { to } \mathrm{T}+3\end{array}$} & \multicolumn{2}{|c|}{$\begin{array}{l}\text { Event Window: } \mathrm{T}-3 \\
\text { to } \mathrm{T}+10\end{array}$} \\
\hline & Variable 1 & Variable 2 & Variable 1 & Variable 2 & Variable 1 & Variable 2 \\
\hline Mean & 0.0010 & -0.0055 & 0.0014 & -0.0072 & 0.0040 & -0.0113 \\
\hline Variance & 0.010 & 3.54 & 0.034135 & 8.8 & 0.096304 & 21.8 \\
\hline Observations & 657 & 657 & 656 & 656 & 656 & 656 \\
\hline Pearson Correlation & 0.5043 & & 0.5701 & & 0.6247 & \\
\hline $\begin{array}{l}\text { Hypothesized Mean } \\
\text { Difference }\end{array}$ & 0 & & 0 & & 0 & \\
\hline $\mathrm{df}$ & 656 & & 655 & & 655 & \\
\hline t-Stat & 2.8615 & & 2.4497 & & 2.7659 & \\
\hline $\mathrm{P}(\mathrm{T}<=t)$ two-tail & 0.0044 & & 0.0146 & & 0.0058 & \\
\hline$t$ Critical two-tail & 1.9636 & & 1.9636 & & 1.9636 & \\
\hline
\end{tabular}

Further robustness checks are undertaken by removing outliers, first at the $1 \%$ level (see Table 4, Panel A). These results support those reported in Table 3. The results for the test after removing $2 \%$ of the outliers are reported in Table 4, Panel B, and suggest that the null hypothesis is accepted for the longer event windows. However, when $1 \%$ of the outliers are removed, Panel C column 2 shows unexpected results for the event window $\mathrm{T}-1$ to $\mathrm{T}+1$ for credit rating upgrades. The $t$-test results show that changes in credit ratings indeed have a significant impact on changes in security prices. The absolute value of $t$ (2.63) is larger than the $t$-critical value (1.96) and the $p$-value is 0.004 , indicating that upgrades have a significant impact on the returns of securities. This result suggests significant investor reactions immediately after a change in credit rating but that trading returns to normal over the next few days and, therefore, the longer event windows show no significant abnormal returns. Applying the method of Galai et al. (2008) and removing $2 \%$ of the outliers, we find no significant impact on security prices from upward changes in credit ratings (results not provided but available on request). 
Table 4.

\section{T-Tests for Credit Ratings Without Outliers}

The table shows the $t$-tests for credit ratings after removing outliers. Panel A reports the t-test statistics for the credit rating downgrade after removing $1 \%$ of the outliers for the event windows $\mathrm{T}-1$ to $\mathrm{T}+1, \mathrm{~T}-3$ to $\mathrm{T}+3$, and $\mathrm{T}-3$ to $\mathrm{T}+10$ for the years 2006 to 2015. Panel B reports the $t$-test statistics for the credit rating downgrade after removing $2 \%$ of the outliers for the event windows $\mathrm{T}-1$ to $\mathrm{T}+1, \mathrm{~T}-3$ to $\mathrm{T}+3$, and $\mathrm{T}-3$ to $\mathrm{T}+10$ for the years 2006 to 2015 . Panel C reports the $t$-test statistics for the credit rating upgrade after removing outliers $1 \%$ and $2 \%$ outliers, respectively for the event window T-1 to T+1 for the years 2006 to 2015 .

\begin{tabular}{|c|c|c|c|}
\hline \multicolumn{4}{|l|}{ Panel A } \\
\hline $\begin{array}{l}\text { Downgrade in credit rating } \\
(2006-2015)\end{array}$ & $\begin{array}{c}\text { Window: } \mathrm{T}-1 \text { to } \mathrm{T}+1 \\
1 \% \text { of outliers } \\
\text { removed }\end{array}$ & $\begin{array}{c}\text { Window: } \mathrm{T}-3 \text { to } \mathrm{T}+3 \\
1 \% \text { of outliers } \\
\text { removed }\end{array}$ & $\begin{array}{c}\text { Window: } \mathrm{T}-3 \text { to } \mathrm{T}+10 \\
1 \% \text { of outliers } \\
\text { removed }\end{array}$ \\
\hline Observations & 650 & 649 & 649 \\
\hline$t$-Stat & 4.0554 & 2.4516 & 2.0145 \\
\hline $\mathrm{P}(\mathrm{T}<=t)$ two-tail & 0.0001 & 0.0145 & 0.0444 \\
\hline$t$ Critical two-tail & 1.9636 & 1.9636 & 1.9636 \\
\hline \multicolumn{4}{|l|}{ Panel B } \\
\hline $\begin{array}{l}\text { Downgrade in credit rating } \\
(2006-2015)\end{array}$ & $\begin{array}{c}\text { Window: } \mathrm{T}-1 \text { to } \\
\mathrm{T}+1 \\
\begin{array}{c}2 \% \text { of outliers } \\
\text { removed }\end{array}\end{array}$ & $\begin{array}{c}\text { Window: } \mathrm{T}-3 \text { to } \\
\mathrm{T}+3 \\
\begin{array}{c}2 \% \text { of outliers } \\
\text { removed }\end{array}\end{array}$ & $\begin{array}{c}\text { Window: } \mathrm{T}-3 \text { to } \\
\mathrm{T}+10 \\
\begin{array}{c}2 \% \text { of outliers } \\
\text { removed }\end{array}\end{array}$ \\
\hline Observations & 644 & 643 & 643 \\
\hline$t$-Stat & 4.0016 & 1.9079 & 1.5099 \\
\hline $\mathrm{P}(\mathrm{T}<=t)$ two-tail & 0.0001 & 0.0569 & 0.1316 \\
\hline$t$ Critical two-tail & 1.9637 & 1.9637 & 1.9637 \\
\hline \multicolumn{4}{|l|}{ Panel C } \\
\hline $\begin{array}{l}\text { Upgrade in credit rating } \\
(2006-2015)\end{array}$ & $\begin{array}{l}\text { Window: } \mathrm{T}-1 \text { to } \\
\qquad+1\end{array}$ & $\begin{array}{c}\text { Window: } \mathrm{T}-1 \text { to } \\
\mathrm{T}+1 \\
\begin{array}{c}1 \% \text { of outliers } \\
\text { removed }\end{array} \\
\end{array}$ & $\begin{array}{c}\text { Window: } \mathrm{T}-1 \text { to } \\
\mathrm{T}+1 \\
\begin{array}{c}2 \% \text { of outliers } \\
\text { removed }\end{array} \\
\end{array}$ \\
\hline Observations & 695 & 695 & 688 \\
\hline$t$-Stat & -2.6381 & -1.9997 & -1.1129 \\
\hline $\mathrm{P}(\mathrm{T}<=t)$ two-tail & 0.0085 & 0.0459 & 0.2661 \\
\hline T Critical two-tail & 1.9634 & 1.9634 & 1.96342 \\
\hline
\end{tabular}

The results of statistical tests for the sample that includes data for the two years preceding the global credit crisis are in Table 5. Upgrades of credit ratings over the longer event windows ( $\mathrm{T}-3$ to $\mathrm{T}+3$ and $\mathrm{T}-3$ to $\mathrm{T}+10$ ) have no significant impact on security prices compared to the short three-day event window ( $\mathrm{T}-1$ to $\mathrm{T}+1)$, thus rejecting the null hypothesis. However, the exact opposite results are observed for the impact of downgrades of credit ratings on security prices. Downward changes in credit ratings significantly impact returns for the two longer event windows. This is consistent with the results of prior studies. However, tests of the impact of downgrades over the event window of three days (T-1 to $T+1)$ for the 2006-2007 period yields conflicting results compared to those for the whole data set. The $t$-values in this case are smaller than the $t$-critical value, suggesting that changes in credit ratings do not lead to significant abnormal returns on securities. 
Table 5.

T-Tests for Credit Ratings Without 1\% and 2\% Outliers for 2006 to 2007

The table shows $t$-tests for credit ratings without $1 \%$ and $2 \%$ outliers. Panel A reports the $t$-test statistics for the credit rating upgrades after removing $1 \%$ and $2 \%$ outliers for the period 2006 to 2007. Panel B reports the $t$-test statistics for the credit rating downgrades after removing $1 \%$ and $2 \%$ outliers for the period 2006 to 2007 .

\begin{tabular}{|c|c|c|c|c|c|c|c|c|c|}
\hline \multicolumn{10}{|l|}{ Panel A } \\
\hline $\begin{array}{l}\text { Upgrade } \\
\text { in credit rating }\end{array}$ & \multicolumn{3}{|c|}{ Window: $\mathrm{T}-1$ to $\mathrm{T}+1$} & \multicolumn{3}{|c|}{ Window: $\mathrm{T}-3$ to $\mathrm{T}+3$} & \multicolumn{3}{|c|}{ Window: $\mathrm{T}-3$ to $\mathrm{T}+10$} \\
\hline Outliers Removed & None & $1 \%$ & $2 \%$ & None & $1 \%$ & $2 \%$ & None & $1 \%$ & $2 \%$ \\
\hline Observations & 172 & 170 & 169 & 172 & 170 & 169 & 172 & 170 & 169 \\
\hline$t$-Stat & -5.0501 & -5.1188 & -5.1001 & -0.7721 & 0.2114 & 0.4233 & 0.3168 & 1.1331 & 1.0688 \\
\hline $\mathrm{P}(\mathrm{T}<=t)$ two-tail & 0.0000 & 0.0000 & 0.0000 & 0.4411 & 0.8328 & 0.6726 & 0.7517 & 0.2588 & 0.2867 \\
\hline$t$ Critical two-tail & 1.9739 & 1.9741 & 1.9742 & 1.9739 & 1.9741 & 1.9742 & 1.9739 & 1.9741 & 1.9742 \\
\hline \multicolumn{10}{|l|}{ Panel B } \\
\hline $\begin{array}{l}\text { Downgrade } \\
\text { in credit rating }\end{array}$ & \multicolumn{3}{|c|}{ Window: $\mathrm{T}-1$ to $\mathrm{T}+1$} & \multicolumn{3}{|c|}{ Window: $\mathrm{T}-3$ to $\mathrm{T}+3$} & \multicolumn{3}{|c|}{ Window: $\mathrm{T}-3$ to $\mathrm{T}+10$} \\
\hline Outliers Removed & None & $1 \%$ & $2 \%$ & None & $1 \%$ & $2 \%$ & None & $1 \%$ & $2 \%$ \\
\hline Observations & 128 & 127 & 125 & 127 & 126 & 124 & 127 & 126 & 124 \\
\hline$t$-Stat & 0.8466 & 1.7664 & 1.4947 & 1.9922 & 1.6232 & 3.1331 & 2.5604 & 2.3325 & 2.4495 \\
\hline $\mathrm{P}(\mathrm{T}<=t)$ two-tail & 0.3988 & 0.0798 & 0.1375 & 0.0485 & 0.1071 & 0.0022 & 0.7517 & 0.0213 & 0.0157 \\
\hline$t$ Critical two-tail & 1.9788 & 1.9790 & 1.9793 & 1.9790 & 1.9791 & 1.9794 & 1.9790 & 1.9791 & 1.9794 \\
\hline
\end{tabular}

The GFC-2008 results are reported in Table 6 . The results suggest that investors did not react strongly then to changes in credit ratings. The results in Table 6 show that the only event window that rejects the null hypothesis is that from $T-1$ to $T+1$ for credit rating upgrades. Over the three-day event window for 2008, the $t$-values are larger than the $t$-critical value in tests of the relationship between changes in stock prices and changes in credit ratings. Further robustness checks are undertaken for this window after the outliers at the $1 \%$ and $2 \%$ levels are removed. The results confirm those for the full-sample data tested for this event window.

Table 6.

T-Tests for Credit Ratings Without 1\% and 2\% Outliers for 2008

The table shows $t$-tests for credit ratings without $1 \%$ and $2 \%$ outliers for 2008. Panel A reports the $t$-test statistics for the credit rating upgrades after removing $1 \%$ and $2 \%$ outliers for the year 2008. Panel B reports the $t$-test statistics for the credit rating downgrades after removing $1 \%$ and $2 \%$ outliers for the year 2008 .

\begin{tabular}{lccccccccc}
\hline Panel A & \multicolumn{10}{l}{$\begin{array}{l}\text { Upgrade } \\
\text { in credit rating }\end{array}$} & \multicolumn{1}{l}{ Window: T-1 to T+1 } & \multicolumn{2}{c}{ Window: T-3 to T+3 } & \multicolumn{3}{c}{ Window: T-3 to T+10 } \\
\hline Outliers Removed & None & $\mathbf{1 \%}$ & $\mathbf{2} \%$ & None & $\mathbf{1 \%}$ & $\mathbf{2} \%$ & None & $\mathbf{1 \%}$ & $\mathbf{2} \%$ \\
\hline Observations & 60 & 59 & 59 & 60 & 59 & 59 & 60 & 59 & 59 \\
$t-S t a t$ & 2.4346 & 2.3745 & 2.3745 & 0.0172 & -0.1787 & -0.1787 & -1.674 & -0.7348 & -0.7348 \\
$P(T<=t)$ two-tail & 0.0180 & 0.0209 & 0.0209 & 0.9863 & 0.8588 & 0.8588 & 0.099 & 0.4654 & 0.4654 \\
$t$ Critical two-tail & 2.0001 & 2.0017 & 2.0017 & 2.0001 & 2.0017 & 2.0017 & 2.000 & 2.0017 & 2.0017 \\
\hline
\end{tabular}


Table 6.

T-Tests for Credit Ratings Without 1\% and 2\% Outliers for 2008 (Continued)

\begin{tabular}{|c|c|c|c|c|c|c|c|c|c|}
\hline \multicolumn{10}{|l|}{ Panel B } \\
\hline $\begin{array}{l}\text { Downgrade } \\
\text { in credit rating }\end{array}$ & \multicolumn{3}{|c|}{ Window: $\mathrm{T}-1$ to $\mathrm{T}+1$} & \multicolumn{3}{|c|}{ Window: $\mathrm{T}-3$ to $\mathrm{T}+3$} & \multicolumn{3}{|c|}{ Window: $\mathrm{T}-3$ to $\mathrm{T}+10$} \\
\hline Outliers Removed & None & $1 \%$ & $2 \%$ & None & $1 \%$ & $2 \%$ & None & $1 \%$ & $2 \%$ \\
\hline Observations & 120 & 119 & 118 & 120 & 119 & 118 & 120 & 119 & 118 \\
\hline$t$-Stat & 0.3654 & 1.0764 & 0.8055 & 0.0063 & 0.3599 & -0.0713 & 0.3418 & -0.1790 & -0.4460 \\
\hline $\mathrm{P}(\mathrm{T}<=t)$ two-tail & 0.7154 & 0.2840 & 0.4221 & 0.9950 & 0.7196 & 0.9432 & 0.7331 & 0.8583 & 0.6564 \\
\hline$t$ Critical two-tail & 1.9801 & 1.9803 & 1.9804 & 1.9801 & 1.9803 & 1.9804 & 1.9801 & 1.9803 & 1.9804 \\
\hline
\end{tabular}

Results for the six-year period following the GFC occupy Table 7. The ratings upgrades of firms' securities over this period significantly influence daily returns for the 14-day event window from T-3 to T+10. The $t$-values exceed $t$-critical values $(p$-value $=0.005)$, suggesting that the null hypothesis of no significant changes to returns due to changes in credit ratings is rejected. This is contrary to the findings for the other periods tested in this study and of the earlier research reviewed. Robustness checks with outliers removed yield similar results, thus rejecting the null hypothesis. Tests for statistical significance over the two shorter event windows of three days ( $\mathrm{T}-1$ to $\mathrm{T}+1)$ and seven days $(\mathrm{T}-3$ to $\mathrm{T}+3)$ yield similar results, that is, there is no significant market reaction to upgrades of credit ratings.

The results for credit rating downgrades suggest that the securities market does react significantly to them. All three event windows tested show high $t$-values compared to their respective $t$-critical values. Further robustness checks with $1 \%$ of the outliers removed confirm these results. However, when $2 \%$ of the outliers are removed over the event windows $\mathrm{T}-3$ to $\mathrm{T}+3$ and $\mathrm{T}-3$ to $\mathrm{T}+10$, the results show that changes in credit ratings have no effect on returns.

Table 7.

T-Tests for Credit Ratings Without 1\% and 2\% Outliers for 2009 to 2015

The table shows $t$-tests for credit ratings without $1 \%$ and $2 \%$ outliers for 2009 to 2015 . Panel A reports the $t$-test statistics for the credit rating upgrades after removing $1 \%$ and $2 \%$ outliers for the period 2009 to 2015 . Panel B reports the $t$-test statistics for the credit rating downgrades after removing 1\% and 2\% outliers for the period 2009 to 2015.

\begin{tabular}{|c|c|c|c|c|c|c|c|c|c|}
\hline \multicolumn{10}{|l|}{ Panel A } \\
\hline $\begin{array}{l}\text { Upgrade } \\
\text { in credit rating }\end{array}$ & \multicolumn{3}{|c|}{ Window: $\mathrm{T}-1$ to $\mathrm{T}+1$} & \multicolumn{3}{|c|}{ Window: $\mathrm{T}-3$ to $\mathrm{T}+3$} & \multicolumn{3}{|c|}{ Window: $\mathrm{T}-3$ to $\mathrm{T}+10$} \\
\hline Outliers Removed & None & $1 \%$ & $2 \%$ & None & $1 \%$ & $2 \%$ & None & $1 \%$ & $2 \%$ \\
\hline Observations & 470 & 465 & 461 & 470 & 465 & 461 & 470 & 465 & 461 \\
\hline$t$-Stat & -1.2650 & -0.6901 & -0.2500 & -0.8431 & 1.4269 & 1.4095 & 2.8167 & 4.5490 & 4.8557 \\
\hline $\mathrm{P}(\mathrm{T}<=t)$ two-tail & 0.2065 & 0.4905 & 0.8027 & 0.3996 & 0.1543 & 0.1594 & 0.0051 & 0.0000 & 0.0000 \\
\hline$t$ Critical two-tail & 1.9650 & 1.9651 & 1.9651 & 1.9650 & 1.9651 & 1.9651 & 1.9650 & 1.9651 & 1.9651 \\
\hline
\end{tabular}


Table 7.

T-Tests for Credit Ratings Without 1\% and 2\% Outliers for 2009 to 2015 (Continued)

\begin{tabular}{|c|c|c|c|c|c|c|c|c|c|}
\hline \multicolumn{10}{|l|}{ Panel B } \\
\hline $\begin{array}{l}\text { Downgrade } \\
\text { in credit rating }\end{array}$ & \multicolumn{3}{|c|}{ Window: $\mathrm{T}-1$ to $\mathrm{T}+1$} & \multicolumn{3}{|c|}{ Window: $\mathrm{T}-3$ to $\mathrm{T}+3$} & \multicolumn{3}{|c|}{ Window: $\mathrm{T}-3$ to $\mathrm{T}+10$} \\
\hline Outliers Removed & None & $1 \%$ & $2 \%$ & None & $1 \%$ & $2 \%$ & None & $1 \%$ & $2 \%$ \\
\hline Observations & 409 & 405 & 401 & 409 & 405 & 401 & 409 & 405 & 401 \\
\hline$t$-Stat & 3.9592 & 3.7198 & 3.4993 & 2.9708 & 2.1730 & 1.8263 & 2.8167 & 2.0867 & 1.6431 \\
\hline $\mathrm{P}(\mathrm{T}<=t)$ two-tail & 0.0001 & 0.0002 & 0.0005 & 0.0031 & 0.0304 & 0.0685 & 0.0048 & 0.0375 & 0.1012 \\
\hline$t$ Critical two-tail & 1.9658 & 1.9658 & 1.9659 & 1.9658 & 1.9659 & 1.9659 & 1.9658 & 1.9659 & 1.9659 \\
\hline
\end{tabular}

The impact ratings changes on returns by different credit rating agencies Fitch, Moody's, and S\&P are reported in Tables 8 to 10. For the primary event window of 14 days, the results over the full sample (2006-2015) show no significant impact on firm share prices due to upward changes in credit ratings by S\&P or Moody's. However, when Fitch adjusts a credit rating upwards, the market reacts strongly, with a $t$-value of 4.78 , which is significantly higher than the $t$-critical value of 1.97 . However, robustness checks over the shorter event windows fail to confirm these findings, implying that the market reacts this strongly only four days or more after the rating change announcement.

Results from announcements of downward changes in credit ratings indicate that the market only reacts strongly to changes announced by Moody's. Over the 14-day event window ( $\mathrm{T}-3$ to $\mathrm{T}+10)$, the $t$-values are much larger than the $t$-critical value, showing that the abnormal returns observed are due to the events occurring, that is, changes in credit ratings. These results are confirmed for Moody's with robustness checks over the shorter event windows $\mathrm{T}-1$ to $\mathrm{T}+1$ and $\mathrm{T}-3$ to $\mathrm{T}+10$. The results of downward changes for the other two rating agencies reveal that announcements have no significant impact on security prices. These results are consistent over all three event windows.

Analysis of the rating changes by the individual rating agencies shows very little significant impact on the prices of securities before the global credit crisis. For all three agencies in this study, neither an upward nor a downward change in credit ratings has an abnormal impact over the primary event window of 14 days. The robustness check for the three-day period reveals that upward rating changes by S\&P and Fitch have a significant impact on share prices. The inconsistency in the longer event window is also observed for downward changes by S\&P and Moody's over the mid-range window T-3 to T+3. It is, however, important to note that the number of observations over this period is relatively small, especially observations recorded for Moody's, with only 15 upgrades and 18 downgrades. To achieve a more reliable result, it is recommended that the sample be extended to a few years earlier.

The comparative analysis of the impact of ratings announcement by the separate rating agencies reveals that the market is reacting more strongly to changes since the global credit crisis than before it. Investors relying on rating announcements by Fitch reacted the most to any changes. The results indicate that 
an announcement of an upward change by Fitch over all three event windows significantly impacted abnormal returns of security prices. Announcements of downward changes by Fitch also produced significant results over the two shorter event windows.

Results from announcements made by Moody's indicate that followers of their rating changes only reacted significantly to downward changes. These results are consistent with earlier research that concludes that entities tend to release positive information sooner and thus upward credit rating changes do not come as a surprise to investors (Chen et al., 2001; Bae et al., 2006; Alsakka and Gwilym, 2012).

Rating announcements by S\&P do not appear to signal new information to the market, since the results show that the only significant impact on security prices is observed in reaction to upward rating changes over the short three-day event window that is used as a robustness check.

Table 8.

\section{T-Tests for Credit Ratings Reported by S\&P, Fitch, and Moody's} for the Period 2006 to 2015

The table shows $t$-tests for credit ratings reported by S\&P, Fitch, and Moody's for the period 2006 to 2015. Panel A reports the $t$-test statistics for the credit rating upgrades reported by S\&P, Fitch, and Moody's for the period 2006 to 2015. Panel B reports the $t$-test statistics for the credit rating downgrades reported by S\&P, Fitch, and Moody's for the period 2006 to 2015.

\begin{tabular}{|c|c|c|c|c|c|c|c|c|c|}
\hline \multicolumn{10}{|l|}{ Panel A } \\
\hline $\begin{array}{l}\text { Upgrade } \\
\text { in credit rating }\end{array}$ & \multicolumn{3}{|c|}{ Window: $\mathrm{T}-1$ to $\mathrm{T}+1$} & \multicolumn{3}{|c|}{ Window: $\mathrm{T}-3$ to $\mathrm{T}+3$} & \multicolumn{3}{|c|}{ Window: $\mathrm{T}-3$ to $\mathrm{T}+10$} \\
\hline $\begin{array}{l}\text { Outliers } \\
\text { Removed* }\end{array}$ & S\&P & Fitch & Moody's & S\&P & Fitch & Moody's & S\&P & Fitch & Moody's \\
\hline Observations & 441 & 199 & 62 & 441 & 199 & 62 & 441 & 199 & 62 \\
\hline$t$-Stat & -3.1869 & 1.2235 & -1.5342 & -1.3068 & 1.8126 & -1.2468 & -0.8807 & 4.7847 & 1.6750 \\
\hline $\mathrm{P}(\mathrm{T}<=t)$ two-tail & 0.0015 & 0.2226 & 0.1310 & 0.1920 & 0.0714 & 0.2172 & 0.3790 & 0.0000 & 0.0991 \\
\hline$t$ Critical two-tail & 1.9654 & 1.9720 & 1.9996 & 1.9654 & 1.9720 & 1.9996 & 1.9654 & 1.9720 & 1.9996 \\
\hline \multicolumn{10}{|l|}{ Panel B } \\
\hline $\begin{array}{l}\text { Downgrade } \\
\text { in credit rating }\end{array}$ & \multicolumn{3}{|c|}{ Window: $\mathrm{T}-1$ to $\mathrm{T}+1$} & \multicolumn{3}{|c|}{ Window: $\mathrm{T}-3$ to $\mathrm{T}+3$} & \multicolumn{3}{|c|}{ Window: $\mathrm{T}-3$ to $\mathrm{T}+10$} \\
\hline Outliers Removed & S\&P & Fitch & Moody's & S\&P & Fitch & Moody's & S\&P & Fitch & Moody's \\
\hline Observations & 363 & 187 & 107 & 363 & 186 & 107 & 363 & 186 & 107 \\
\hline$t$-Stat & 1.7954 & 0.3007 & 3.5149 & 1.3410 & -0.7536 & 3.8335 & 0.8361 & 0.1014 & 3.9794 \\
\hline $\mathrm{P}(\mathrm{T}<=t)$ two-tail & 0.0734 & 0.7639 & 0.0006 & 0.1808 & 0.4520 & 0.0002 & 0.4036 & 0.9193 & 0.0001 \\
\hline$t$ Critical two-tail & 1.9665 & 1.9728 & 1.9826 & 1.9665 & 1.9729 & 1.9826 & 1.9665 & 1.9729 & 1.9826 \\
\hline
\end{tabular}


Table 9.

T-Tests for Credit Ratings Reported by S\&P, Fitch, and Moody's for the Period 2006 to 2007

The table shows $t$-tests for credit ratings reported by S\&P, Fitch, and Moody's for the period 2006 to 2007. Panel A reports the $t$-test statistics for the credit rating upgrades reported by S\&P, Fitch, and Moody's for the period 2006 to 2007. Panel B reports the $t$-test statistics for the credit rating downgrades reported by S\&P, Fitch, and Moody's for the period 2006 to 2007.

\begin{tabular}{|c|c|c|c|c|c|c|c|c|c|}
\hline \multicolumn{10}{|l|}{ Panel A } \\
\hline $\begin{array}{l}\text { Upgrade } \\
\text { in credit rating }\end{array}$ & \multicolumn{3}{|c|}{ Window: $\mathrm{T}-1$ to $\mathrm{T}+1$} & \multicolumn{3}{|c|}{ Window: $\mathrm{T}-3$ to $\mathrm{T}+3$} & \multicolumn{3}{|c|}{ Window: $\mathrm{T}-3$ to $\mathrm{T}+10$} \\
\hline $\begin{array}{l}\text { Outliers } \\
\text { Removed* }\end{array}$ & S\&P & Fitch & Moody's & S\&P & Fitch & Moody's & S\&P & Fitch & Moody's \\
\hline Observations & 95 & 62 & 15 & 95 & 62 & 15 & 95 & 62 & 15 \\
\hline$t$-Stat & -4.4919 & -2.1226 & -1.6471 & -1.0665 & 0.1307 & 1.2994 & -0.1348 & -0.4265 & 1.9516 \\
\hline $\mathrm{P}(\mathrm{T}<=t)$ two-tail & -0.0000 & 0.0379 & 0.1218 & 0.2889 & 0.8964 & 0.2148 & 0.8931 & 0.6314 & 0.0713 \\
\hline t Critical two-tail & 1.9855 & 1.9996 & 2.1448 & 1.9855 & 1.9996 & 2.1448 & 1.9855 & 1.9996 & 2.1448 \\
\hline \multicolumn{10}{|l|}{ Panel B } \\
\hline $\begin{array}{l}\text { Downgrade } \\
\text { in credit rating }\end{array}$ & \multicolumn{3}{|c|}{ Window: $\mathrm{T}-1$ to $\mathrm{T}+1$} & \multicolumn{3}{|c|}{ Window: $\mathrm{T}-3$ to $\mathrm{T}+3$} & \multicolumn{3}{|c|}{ Window: $\mathrm{T}-3$ to $\mathrm{T}+10$} \\
\hline Outliers Removed & S\&P & Fitch & Moody's & S\&P & Fitch & Moody's & S\&P & Fitch & Moody's \\
\hline Observations & 72 & 38 & 18 & 72 & 37 & 18 & 72 & 37 & 18 \\
\hline$t$-Stat & 1.1633 & -1.1564 & 1.1286 & 2.1679 & -1.8365 & 2.1910 & 1.9297 & 1.0217 & 1.3210 \\
\hline $\mathrm{P}(\mathrm{T}<=t)$ two-tail & 0.2486 & 0.2455 & 0.2748 & 0.3352 & 0.0746 & 0.0426 & 0.0576 & 0.3137 & 0.2040 \\
\hline$t$ Critical two-tail & 1.9939 & 2.0262 & 2.1098 & 1.9939 & 2.0281 & 2.1098 & 1.9939 & 2.0281 & 2.1098 \\
\hline
\end{tabular}

Table 10.

T-Tests for Credit Ratings Reported by S\&P, Fitch, and Moody's for the Period 2009 to 2015

The table shows $t$-tests for credit ratings reported by S\&P, Fitch, and Moody's for the period 2009 to 2015. Panel A reports the $t$-test statistics for the credit rating upgrades reported by S\&P, Fitch, and Moody's for the period 2009 to 2015. Panel B reports the $t$-test statistics for the credit rating downgrades reported by S\&P, Fitch, and Moody's for the period 2009 to 2015.

\begin{tabular}{|c|c|c|c|c|c|c|c|c|c|}
\hline \multicolumn{10}{|l|}{ Panel A } \\
\hline $\begin{array}{l}\text { Upgrade } \\
\text { in credit rating }\end{array}$ & \multicolumn{3}{|c|}{ Window: $\mathrm{T}-1$ to $\mathrm{T}+1$} & \multicolumn{3}{|c|}{ Window: $\mathrm{T}-3$ to $\mathrm{T}+3$} & \multicolumn{3}{|c|}{ Window: $\mathrm{T}-3$ to $\mathrm{T}+10$} \\
\hline $\begin{array}{l}\text { Outliers } \\
\text { Removed* }\end{array}$ & S\&P & Fitch & Moody's & S\&P & Fitch & Moody's & S\&P & Fitch & Moody's \\
\hline Observations & 302 & 124 & 44 & 302 & 124 & 44 & 302 & 124 & 44 \\
\hline$t$-Stat & -2.4223 & 2.8192 & -1.4087 & -1.0713 & 2.2025 & -1.2381 & 0.3253 & 7.2004 & 0.7509 \\
\hline $\mathrm{P}(\mathrm{T}<=t)$ two-tail & 0.0160 & 0.00561 & 0.1661 & 0.2849 & 0.0295 & 0.2224 & 0.7452 & $5.224 \mathrm{E}-11$ & 0.4568 \\
\hline$t$ Critical two-tail & 1.9679 & 1.97943 & 2.0167 & 1.9679 & 1.9794 & 2.0167 & 1.9679 & 1.9794 & 2.0167 \\
\hline \multicolumn{10}{|l|}{ Panel B } \\
\hline $\begin{array}{l}\text { Downgrade } \\
\text { in credit rating }\end{array}$ & \multicolumn{3}{|c|}{ Window: $\mathrm{T}-1$ to $\mathrm{T}+1$} & \multicolumn{3}{|c|}{ Window: $\mathrm{T}-3$ to $\mathrm{T}+3$} & \multicolumn{3}{|c|}{ Window: $\mathrm{T}-3$ to $\mathrm{T}+10$} \\
\hline $\begin{array}{l}\text { Outliers } \\
\text { Removed* }\end{array}$ & S\&P & Fitch & Moody's & S\&P & Fitch & Moody's & S\&P & Fitch & Moody's \\
\hline Observations & 223 & 114 & 72 & 223 & 114 & 72 & 223 & 114 & 72 \\
\hline t-Stat & -0.0350 & 4.5043 & 3.8775 & 0.2657 & 2.7443 & 3.4141 & 0.5352 & 1.0353 & 3.3398 \\
\hline $\mathrm{P}(\mathrm{T}<=t)$ two-tail & 0.9721 & 0.0000 & 0.0002 & 0.7908 & 0.0071 & 0.0011 & 0.5931 & 0.3027 & 0.0013 \\
\hline$t$ Critical two-tail & 1.9707 & 1.9812 & 1.9939 & 1.9707 & 1.9812 & 1.9939 & 1.9707 & 1.9812 & 1.9939 \\
\hline
\end{tabular}


The effect of a change in credit rating over different classes or within a class are summarized in Tables 11 to 13 . Evaluation of the data over the entire period (2006-2015) yields mixed results. Announcements of upgrades in credit ratings have significant impacts on abnormal returns when the rating grade moves up within the investment-grade category, as well as for upward movements from speculative- to investment-grade ratings. The results for the full data set tested for downgrades show that rating changes have a significant impact only for downgrades within the investment-grade class. These findings are in contrast to those of previous studies which conclude that announcements downgrades of credit ratings over classes have a significant impact on security prices, with no significant impact observed for upgrades (Choy et al., 2006; Halek and Eckles, 2010; Freitas and Minardi, 2013).

Breaking the evaluation of rating changes up over the two periods surrounding the GFC yields the following results. For the period 2006 to 2007, the results indicate that an announcement of a change in ratings (upwards or downwards) has no effect on returns. There is one exception, however, which is for upgrades of credit ratings within the investment-grade class over the short-term event window of three days. These results match those for the full data set but once again contradict the evidence of earlier studies.

Regarding the results during the period after the global credit crisis, we find evidence that suggests the market is now taking greater note of changes in credit ratings. Our findings indicate that an announcement of a credit rating upgrade where the rating moves from speculative grade to investment grade has a significant impact on security prices. The results suggest this for all three event windows tested. However, when evaluating the announcements of downgrades for the period after the global credit crisis, we find the results show a significant impact only when a downgrade is announced for movements within investmentgrade ratings.

Table 11.

\section{$T$-Tests for Between and Within Different Credit Ratings for the Period 2006 to 2015}

The table shows $t$-tests for between and within different credit ratings for the period 2006 to 2015. Panel A reports the $t$-test statistics for the credit rating upgrades between and within different grading classes for the period 2006 to 2015. Panel B reports the $t$-test statistics for the credit rating downgrades between and within different grading classes for the period 2006 to 2015.

\begin{tabular}{lccccccccc}
\hline Panel A & \multicolumn{10}{c}{$\begin{array}{c}\text { Upgrade within } \\
\text { in credit rating }\end{array}$} & \multicolumn{1}{c}{$\begin{array}{c}\text { Upgrade from } \\
\text { Investment grade } \\
\text { Investment grade } \\
\text { quality }\end{array}$} & $\begin{array}{c}\text { Upgrade within } \\
\text { Speculative grade }\end{array}$ \\
\hline Outliers & $\mathrm{T}-\mathbf{1}$ to & $\mathrm{T}-\mathbf{3}$ to & $\mathrm{T}-\mathbf{3}$ to & $\mathrm{T}-\mathbf{1}$ to & $\mathrm{T}-\mathbf{3}$ to & $\mathrm{T}-\mathbf{3}$ to & $\mathrm{T}-\mathbf{1}$ to & $\mathrm{T}-\mathbf{3}$ to & $\mathrm{T}-\mathbf{3}$ to \\
Removed* & $\mathrm{T}+\mathbf{1}$ & $\mathrm{T}+\mathbf{3}$ & $\mathrm{T}+\mathbf{1 0}$ & $\mathrm{T}+\mathbf{1}$ & $\mathrm{T}+\mathbf{3}$ & $\mathrm{T}+\mathbf{1 0}$ & $\mathrm{T}+\mathbf{1}$ & $\mathrm{T}+\mathbf{3}$ & $\mathrm{T}+\mathbf{1 0}$ \\
\hline Observations & 449 & 449 & 449 & 85 & 85 & 85 & 168 & 168 & 168 \\
$t$-Stat & -4.6622 & -2.0186 & 0.4958 & 1.9813 & 2.3275 & 3.2286 & -1.0993 & -1.4234 & -0.6842 \\
$\mathrm{P}(\mathrm{T}<=t)$ two-tail & 0.0000 & 0.0441 & 0.6203 & 0.0508 & 0.0223 & 0.0018 & 0.2732 & 0.1565 & 0.4948 \\
$t$ Critical two-tail & 1.9653 & 1.9653 & 1.9653 & 1.9886 & 1.9886 & 1.9886 & 1.9743 & 1.9743 & 1.9743 \\
\hline
\end{tabular}


Table 11.

T-Tests for Between and Within Different Credit Ratings for the Period 2006 to 2015 (Continued)

\begin{tabular}{|c|c|c|c|c|c|c|c|c|c|}
\hline \multicolumn{10}{|l|}{ Panel B } \\
\hline $\begin{array}{l}\text { Downgrade } \\
\text { in credit rating }\end{array}$ & \multicolumn{3}{|c|}{$\begin{array}{l}\text { Downgrade within } \\
\text { Investment grade }\end{array}$} & \multicolumn{3}{|c|}{$\begin{array}{c}\text { Downgrade from } \\
\text { Investment to } \\
\text { Speculative grade } \\
\text { quality }\end{array}$} & \multicolumn{3}{|c|}{$\begin{array}{l}\text { Downgrade within } \\
\text { Speculative grade }\end{array}$} \\
\hline $\begin{array}{l}\text { Outliers } \\
\text { Removed* }\end{array}$ & $\begin{array}{c}\mathrm{T}-1 \text { to } \\
\mathrm{T}+1\end{array}$ & $\begin{array}{c}\mathrm{T}-3 \text { to } \\
\mathrm{T}+3\end{array}$ & $\begin{array}{l}\mathrm{T}-3 \text { to } \\
\mathrm{T}+10\end{array}$ & $\begin{array}{c}\mathrm{T}-1 \text { to } \\
\mathrm{T}+1\end{array}$ & $\begin{array}{c}\mathrm{T}-3 \text { to } \\
\mathrm{T}+3\end{array}$ & $\begin{array}{c}\mathrm{T}-3 \text { to } \\
\mathrm{T}+10\end{array}$ & $\begin{array}{c}\mathrm{T}-1 \text { to } \\
\mathrm{T}+1\end{array}$ & $\begin{array}{c}\mathrm{T}-3 \text { to } \\
\mathrm{T}+3\end{array}$ & $\begin{array}{l}\mathrm{T}-3 \text { to } \\
\mathrm{T}+10\end{array}$ \\
\hline Observations & 512 & 511 & 511 & 49 & 49 & 49 & 96 & 96 & 96 \\
\hline$t$-Stat & 3.1989 & 3.2059 & 3.5014 & 0.5106 & 0.7492 & 0.5684 & 2.0175 & 1.3656 & 1.5709 \\
\hline $\mathrm{P}(\mathrm{T}<=t)$ two-tail & 0.0015 & 0.0014 & 0.0005 & 0.6120 & 0.4574 & 0.5714 & 0.0465 & 0.1753 & 0.1195 \\
\hline$t$ Critical two-tail & 1.9646 & 1.9646 & 1.9646 & 2.0106 & 2.0106 & 2.0106 & 1.9853 & 1.9853 & 1.9853 \\
\hline
\end{tabular}

Table 12.

T-Tests for Between and Within Different Credit Ratings for the Period 2006 to 2007

The table shows $t$-tests for between and within different credit ratings for the period 2006 to 2007. Panel A reports the $t$-test statistics for the credit rating upgrades between and within different grading classes for the period 2006 to 2007. Panel B reports the $t$-test statistics for the credit rating downgrades between and within different grading classes for the period 2006 to 2007.

\begin{tabular}{|c|c|c|c|c|c|c|c|c|c|}
\hline \multicolumn{10}{|l|}{ Panel A } \\
\hline $\begin{array}{l}\text { Upgrade } \\
\text { in credit rating }\end{array}$ & \multicolumn{3}{|c|}{$\begin{array}{l}\text { Upgrade within } \\
\text { Investment grade }\end{array}$} & \multicolumn{3}{|c|}{$\begin{array}{c}\text { Upgrade from } \\
\text { Speculative to } \\
\text { Investment grade } \\
\text { quality }\end{array}$} & \multicolumn{3}{|c|}{$\begin{array}{l}\text { Upgrade within } \\
\text { Speculative grade }\end{array}$} \\
\hline Outliers & T-1 to & T-3 to & T-3 to & $\mathrm{T}-1$ to & T-3 to & T-3 to & T-1 to & T-3 to & $\mathrm{T}-3$ to \\
\hline Removed* & $\mathrm{T}+1$ & $\mathrm{~T}+3$ & $\mathrm{~T}+10$ & $\mathrm{~T}+1$ & $\mathrm{~T}+3$ & $\mathrm{~T}+10$ & $\mathrm{~T}+1$ & $\mathrm{~T}+3$ & $\mathrm{~T}+10$ \\
\hline Observations & 120 & 120 & 120 & 14 & 14 & 14 & 38 & 38 & 38 \\
\hline$t$-Stat & -3.5181 & -0.5605 & 0.3042 & -0.4123 & -0.0397 & 1.7238 & -0.7764 & -0.6660 & -0.6642 \\
\hline $\mathrm{P}(\mathrm{T}<=t)$ two-tail & 0.0006 & 0.5762 & 0.7615 & 0.6869 & 0.9690 & 0.1084 & 0.4425 & 0.5096 & 0.5107 \\
\hline$t$ Critical two-tail & 1.9801 & 1.9801 & 1.9801 & 2.1604 & 2.1604 & 2.1604 & 2.0265 & 2.0262 & 2.0262 \\
\hline \multicolumn{10}{|l|}{ Panel B } \\
\hline $\begin{array}{l}\text { Downgrade } \\
\text { in credit rating }\end{array}$ & \multicolumn{3}{|c|}{$\begin{array}{l}\text { Downgrade within } \\
\text { Investment grade }\end{array}$} & \multicolumn{3}{|c|}{$\begin{array}{c}\text { Downgrade from } \\
\text { Investment to } \\
\text { Speculative grade } \\
\text { quality }\end{array}$} & \multicolumn{3}{|c|}{$\begin{array}{l}\text { Downgrade within } \\
\text { Speculative grade }\end{array}$} \\
\hline $\begin{array}{l}\text { Outliers } \\
\text { Removed* }\end{array}$ & $\begin{array}{c}\mathrm{T}-1 \text { to } \\
\mathrm{T}+1\end{array}$ & $\begin{array}{c}\mathrm{T}-3 \text { to } \\
\mathrm{T}+3\end{array}$ & $\begin{array}{l}\mathrm{T}-3 \text { to } \\
\mathrm{T}+10\end{array}$ & $\begin{array}{c}\mathrm{T}-1 \text { to } \\
\mathrm{T}+1\end{array}$ & $\begin{array}{c}\mathrm{T}-3 \text { to } \\
\mathrm{T}+3\end{array}$ & $\begin{array}{l}\mathrm{T}-3 \text { to } \\
\mathrm{T}+10\end{array}$ & $\begin{array}{c}\mathrm{T}-1 \text { to } \\
\mathrm{T}+1\end{array}$ & $\begin{array}{c}\mathrm{T}-3 \text { to } \\
\mathrm{T}+3\end{array}$ & $\begin{array}{l}\mathrm{T}-3 \text { to } \\
\mathrm{T}+10 \\
\end{array}$ \\
\hline Observations & 91 & 90 & 90 & 13 & 13 & 13 & 23 & 23 & 23 \\
\hline$t$-Stat & -0.5557 & 0.0509 & 1.0830 & -1.1412 & -0.3687 & 0.3164 & 0.4200 & 0.5559 & 0.5441 \\
\hline $\mathrm{P}(\mathrm{T}<=t)$ two-tail & 0.5798 & 0.9596 & 0.2817 & 0.2744 & 0.7183 & 0.7567 & 0.6785 & 0.5839 & 0.5919 \\
\hline t Critical two-tail & 1.9867 & 1.9870 & 1.9870 & 2.1604 & 2.1604 & 2.1604 & 2.0739 & 2.0739 & 2.0739 \\
\hline
\end{tabular}


Table 13.

T-Tests for Between and Within Different Credit Ratings for the Period 2009 to 2015

The table shows $t$-tests for between and within different credit ratings for the period 2009 to 2015. Panel A reports the $t$-test statistics for the credit rating upgrades between and within different grading classes for the period 2009 to 2015. Panel B reports the $t$-test statistics for the credit rating downgrades between and within different grading classes for the period 2009 to 2015.

\begin{tabular}{|c|c|c|c|c|c|c|c|c|c|}
\hline \multicolumn{10}{|l|}{ Panel A } \\
\hline $\begin{array}{l}\text { Upgrade } \\
\text { in credit rating }\end{array}$ & \multicolumn{3}{|c|}{$\begin{array}{l}\text { Upgrade within } \\
\text { Investment grade }\end{array}$} & \multicolumn{3}{|c|}{$\begin{array}{c}\text { Upgrade from } \\
\text { Speculative to } \\
\text { Investment grade } \\
\text { quality }\end{array}$} & \multicolumn{3}{|c|}{$\begin{array}{l}\text { Upgrade within } \\
\text { Speculative grade }\end{array}$} \\
\hline $\begin{array}{l}\text { Outliers } \\
\text { Removed* }\end{array}$ & $\begin{array}{c}\mathrm{T}-1 \text { to } \\
\mathrm{T}+1\end{array}$ & $\begin{array}{c}\mathrm{T}-3 \text { to } \\
\mathrm{T}+3\end{array}$ & $\begin{array}{l}\mathrm{T}-3 \text { to } \\
\mathrm{T}+10\end{array}$ & $\begin{array}{c}\mathrm{T}-1 \text { to } \\
\mathrm{T}+1\end{array}$ & $\begin{array}{c}\mathrm{T}-3 \text { to } \\
\mathrm{T}+3\end{array}$ & $\begin{array}{l}\mathrm{T}-3 \text { to } \\
\mathrm{T}+10\end{array}$ & $\begin{array}{c}\mathrm{T}-1 \text { to } \\
\mathrm{T}+1\end{array}$ & $\begin{array}{c}\mathrm{T}-3 \text { to } \\
\mathrm{T}+3\end{array}$ & $\begin{array}{c}\mathrm{T}-3 \text { to } \\
\mathrm{T}+10\end{array}$ \\
\hline Observations & 297 & 297 & 297 & 63 & 63 & 63 & 110 & 110 & 110 \\
\hline t-Stat & -2.5623 & -0.8086 & 2.0654 & 2.7151 & 2.7377 & 4.0844 & -1.8109 & -1.4866 & -0.1731 \\
\hline $\mathrm{P}(\mathrm{T}<=\mathrm{t})$ two-tail & 0.0109 & 0.4194 & 0.0398 & 0.0086 & 0.0081 & 0.0001 & 0.0729 & 0.1400 & 0.8629 \\
\hline t Critical two-tail & 1.9680 & 1.9680 & 1.9680 & 1.9990 & 1.9990 & 1.9990 & 1.9820 & 1.9820 & 1.9820 \\
\hline \multicolumn{10}{|l|}{ Panel B } \\
\hline $\begin{array}{l}\text { Downgrade } \\
\text { in credit rating }\end{array}$ & \multicolumn{3}{|c|}{$\begin{array}{l}\text { Downgrade within } \\
\text { Investment grade }\end{array}$} & \multicolumn{3}{|c|}{$\begin{array}{l}\text { Downgrade from } \\
\text { Investment to } \\
\text { Speculative grade } \\
\text { quality }\end{array}$} & \multicolumn{3}{|c|}{$\begin{array}{l}\text { Downgrade within } \\
\text { Speculative grade }\end{array}$} \\
\hline $\begin{array}{l}\text { Outliers } \\
\text { Removed* }\end{array}$ & $\begin{array}{c}\mathrm{T}-1 \text { to } \\
\mathrm{T}+1\end{array}$ & $\begin{array}{c}\mathrm{T}-3 \text { to } \\
\mathrm{T}+3\end{array}$ & $\begin{array}{l}\mathrm{T}-3 \text { to } \\
\mathrm{T}+10\end{array}$ & $\begin{array}{c}\mathrm{T}-1 \text { to } \\
\mathrm{T}+1\end{array}$ & $\begin{array}{c}\mathrm{T}-3 \text { to } \\
\mathrm{T}+3\end{array}$ & $\begin{array}{l}\mathrm{T}-3 \text { to } \\
\mathrm{T}+10\end{array}$ & $\begin{array}{c}\mathrm{T}-1 \text { to } \\
\mathrm{T}+1\end{array}$ & $\begin{array}{c}\mathrm{T}-3 \text { to } \\
\mathrm{T}+3\end{array}$ & $\begin{array}{l}\mathrm{T}-3 \text { to } \\
\mathrm{T}+10\end{array}$ \\
\hline Observations & 340 & 340 & 340 & 24 & 24 & 24 & 45 & 45 & 45 \\
\hline $\mathrm{t}$-Stat & 4.5229 & 4.4778 & 4.4937 & 0.8895 & 1.1219 & 0.7734 & 2.6092 & 1.2244 & -0.4111 \\
\hline $\mathrm{P}(\mathrm{T}<=\mathrm{t})$ two-tail & 0.0000 & 0.0000 & 0.0000 & 0.3830 & 0.2735 & 0.4472 & 0.0154 & 0.2273 & 0.6830 \\
\hline t Critical two-tail & 1.9670 & 1.9670 & 1.9670 & 2.0687 & 2.0687 & 2.0687 & 2.0154 & 2.0154 & 2.0154 \\
\hline
\end{tabular}

\section{CONCLUSION}

This study examines how credit rating changes, both upgrades and downgrades, influence returns of firms issuing securities. We examine the impact of credit rating changes on 449 of the S\&P 500 firms for which 10-year daily data are available from 2006 to 2015. Among these 449 companies, 1,359 credit rating changes were announced (702 upwards and 657 downwards). The sample is partitioned into three subperiods to analyse how ratings changes influence returns of an issuing firm's securities before, during, and after the GFC.

We find mixed results for the whole sample. A credit rating downgrade leads to a significant market reaction whereas an upward change has no effect on returnsfindings that corroborate Bissoondoyal-Bheenick and Brooks (2015), who report that rating downgrades do have a significant impact in the Australian and Japanese markets, although this is not the case for rating upgrade announcements. The lack of effect of upgrades is consistent with the idea that firms release favourable or optimistic information faster and, therefore, an upward change in ratings does not deliver fresh information to the investor.

An analysis of the three subperiods before, during, and after the global credit crisis also delivers mixed results. The results for the two years preceding the GFC are mostly consistent with those for the whole sample, apart for the robustness 
check over the three-day event window ( $\mathrm{T}-1$ to $\mathrm{T}+1)$. These inconsistencies are observed for both upward and downward changes in credit ratings.

For the period after the global credit crisis, we find that downward changes in credit ratings produce significant changes in security prices, similar to earlier studies and to the tests for the whole sample. Since the findings for the event window $\mathrm{T}-3$ to $\mathrm{T}+10$ vary from those of earlier studies or for the period before the GFC in this study, this suggests investors take up to 10 days to react to an upward change in credit rating.

Comparison of the results from the period before the global credit crisis (20062007) to the period after it (2009-2015) suggests that the market is more sensitive to the announcements of changes in credit ratings by specific rating agencies. Announcements of upward or downward changes in credit ratings by Fitch have a significant impact on security prices for all the event windows tested, apart from the 14-day downgrade window after the global credit crisis. This result indicates that the market considers Fitch's changes in credit rating important information on which to base investment decisions. And, announcements of downward rating changes by Moody's, as opposed to upward changes, have a significant impact on security prises. This would suggest that users relying on Moody's credit ratings by now view the downward announcement as new and important information and react accordingly.

The impact of announcements of credit rating changes over classes of ratings suggests that the market reacts strongly to upward changes in credit rating from speculative grade to investment grade, as evidenced over all three event windows tested. However, a significant impact is observed for downward rating changes within the investment-grade category, which is more in line with the results of previous studies.

\section{REFERENCES}

Allen, F., \& Carletti, E. (2010). An Overview of the Crisis: Causes, Consequences, and Solutions. International Review of Finance, 10, 1-26.

Alsakka, R., \& ap Gwilym, O. (2012). Foreign Exchange Market Reactions to Sovereign Credit News. Journal of International Money and Finance, 31, 845-864.

Alsakka, R., \& ap Gwilym, O. (2013). Rating Agencies' Signals During the European Sovereign Debt Crisis: Market Impact and Spillovers. Journal of Economic Behavior E Organization, 85, 144-162.

Apergis, N., Payne, J. E., \& Tsoumas, C. (2012). The Impact of Credit Rating Changes on U.S. Banks. Banking and Finance Review, 4, 1-16.

Arner, D. W. (2009). The Global Credit Crisis of 2008: Causes and Consequences. International Lawyer, 43, 91-136.

Avramov, D., Chordia, T., Jostova, G., \& Philipov, A. (2009). Credit Ratings and the Cross-Section of Stock Returns. Journal of Financial Markets, 12, 469-499.

Bae, K.-H., Lim, C., \& Wei, K. C. (2006). Corporate Governance and Conditional Skewness in the World's Stock Markets. Journal of Business, 79, 2999-3028.

Ball, R., \& Brown, P. (n.d.). An Empirical Evaluation of Accounting Numbers. Journal of Accounting Research, 6, 159-178. 
Bernoth, K., Von Hagen, J., \& Schuknecht, L. (2012). Sovereign Risk Premiums in the European Government Bond Market. Journal of International Money and Finance, 31, 975-995.

Broto, C., \& Molina, L. (2016). Sovereign Ratings and Their Asymmetric Response to Fundamentals. Journal of Economic Behavior \& Organization, 206-224.

Brown, S. J., \& Warner, J. B. (1985). Using Daily Stock Returns: The Case of Event Studies. Journal of Financial Economics, 14, 3-31.

Brune, C., \& Liu, P. (2010). The Contagion Effect of Default Risk Insurer Downgrades: The Impact on Insured Municipal Bonds. Journal of Economics and Business, 63, 492-502.

Burrell, G., \& Morgan, G. (1979). Sociological Paradigms and Organizational Analysis. London: Heinemann Books.

Campbel, J. Y., Lo, A. W., \& MacKinlay, G. A. (1996). The Econometrics of Financial Markets. New Jersey: Princeton University Press.

Cantor, R., \& Packer, F. (1994). The Credit Rating Industry. Federal Reserve Bank of New York Quarterly Review, 19, 1-26.

Chen, J., Hong, H., \& Stein, J. C. (2001). Forecasting Crashes: Trading Volume, Past Returns, and Conditional Skewness in Stock Prices. Journal of Financial Economics, 61, 345-381.

Choy, E., Gray, S., \& Ragunathan, V. (2006). Effect of Credit Rating Changes on Australian Stock Returns. Accounting and Finance, 46, 755-769.

Corner, J. L. (2013). Action Research. Action Research PowerPoint Presentation. Hamilton, Waikato, New Zealand: University of Waikato.

Corner, J. L. (2013). Case Study Research. Case Study Research PowerPoint Presentation. Hamilton, Waikato, New Zealand: University of Waikato.

Corner, J. L. (2013). Ethnography. Ethnography PowerPoint Presentation. Hamilton, Waikato, New Zealand: University of Waikato.

Corwin, S. A., \& Lipson, M. L. (2000). Order Flow and Liquidity around NYSE Trading Halts. Journal of Finance, 55, 1771-1801.

Diamond, D. W., \& Rajan, R. (2009). The Credit Crises: Conjectures about the Causes and Remedies. National Bureau of Economic Research.

Dichev, I. D., \& Piotroski, J. D. (2001). The Long-Run Stock Returns Following Bond Ratings Changes. The Journal of Finance, 56, 173-203.

El-Shagi, M. (2010). The Role of Rating Agencies In Financial Crises: Event Studies From The Asian Flu. Cambridge Journal of Economics, 34, 671-685.

Erlenmaier, U. (2011). The Shadow Rating Approach: Experience from Banking Practice. In B. Engelmann, \& R. Rauhmeier, The Basel II Risk Parameters: Estimation, Validation, Stress Testing With Applications to Loan Risk Management (2nd ed., 37-74). New York and Heidelberg: Springer.

Fama, E. F., Fisher, L., Jensen, M. C., \& Roll, R. (1969). The Adjustment of Stock Prices to New Information. International Economic Review, 10, 1-21.

Fatnassi, I., Ftiti, Z., \& Hasnaoui, H. (2014). Stock Market Reactions to Sovereign Credit Rating Changes: Evidence from Four European Countries. The Journal of Applied Business Research, 30, 953-958.

Fitch Ratings. (2013, February). Retrieved April 6, 2013, from Fitch Ratings Web site: http://www.fitchratings.com/web_content/ratings/fitch_ratings_definitions_ and_scales.pdf 
Freitas, N. A., \& Minardi, A. M. (2013). The Impact of Credit Rating Changes in Latin American Stock Markets. Brazilian Administration Review, 10, 439-461.

Galai, D., Kedar-Levy, H. Z., \& Schreiber, B. (2008). Seasonality in Outliers of Daily Stock Returns: A Tail That Wags the Dog? International Review of Financial Analysis, 17, 784-792.

Galil, K., \& Soffer, G. (2011). Good News, Bad News and Rating Announcements: An Empirical Investigation. Journal of Banking E Finance, 35, 3103-3119.

Gärtner, M., Griesbach, B., \& Jung, F. (2011). PIGS or Lambs? The European Sovereign Debt Crisis and the Role of Rating Agencies. International Advances in Economic Research , 17, 288-299.

Gensuk, M. (2003). A Synthesis of Ethnographic Research. Occasional Papers Series - Center for Multilingual, Multicultural Research. Los Angeles, United States of Amercia: University of Southern California.

Gonzalez, F., Haas, F., Johannes, R., Persson, M., Toledo, L., Violi, R., . . . Zins, C. (2004). Market Dynamics Associated with Credit Ratings: A Literature Review. Banque de France Financial Stability Review, 53-76.

Halek, M., \& Eckles, D. L. (2010). Effects of Analysts' Ratings on Insurer Stock Returns: Evidence of Asymmetric Responses. The Journal of Risk and Insurance, 77, 801-827.

Hand, J. R., Holthausen, R. W., \& Leftwich, R. W. (1992). The Effect of Bond Rating Agency Announcements on Bond and Stock Prices. The Journal of Finance, 47, 733-752.

He, Y., Wang, J., \& Wei, J. K. (2011). Do Bond Rating Changes Affect the Information Asymmetry of Stock Trading? Journal of Empirical Finance, 18, 103-116.

Holthausen, R. W., \& Leftwich, R. W. (1986). The Effect of Bond Rating Changes on Common Stock Prices. Journal of Financial Economics, 17, 57-89.

Hudson, R. S., \& Gregoriou, A. (2015). Calculating and Comparing Security Returns is Harder Than You Think: A Comparison Between Logarithmic and Simple Returns. International Review of Financial Analysis, 38, 151-162.

Hughson, E., Stutzer, M., \& Yung, C. (2006). The Misuse of Expected Returns. Financial Analysis Journal, 62, 88-96.

Johansson, R. (2003). Methodologies in Housing. Methodologies in Housing Research. Stockholm: Royal Institute of Technology - Stockholm.

Jorion, P. (2001). Value at Risk: The New Benchmark for Managing Financial Risk (3 ${ }^{\text {rd }}$ ed.). New York: McGraw-Hill.

Kenjegaliev, A., Duygun, M., \& Mamedshakhova, D. (2016). Do Rating Grades Convey Important Information: German Evidence? Economic Modelling, 53, 334-344.

Kim, Y., Kim, T.-H., \& Ergun, T. (2015). The Instability of the Pearson Correlation Coefficient in the Presence of Coincidental Outliers. Finance Research Letters, 13, 243-257.

Kryzanowski, L., \& Nemiroff, H. (2001). Market Quote and Spread Component Cost Behavior Around Trading Halts for Stocks Interlisted on the Montreal and Toronto Stock Exchanges. Financil Review, 36, 115-138.

Lenell, W., \& Boissoneau, R. (1996). Using Causal-Comparitive and Correlational Designs in Conducting Market Research. Journal of Professional Services Marketing, 13, 59-69. 
Li, H., Jeon, B. N., Cho, S.-Y., \& Chiang, T. C. (2008). The Impact of Sovereign Rating Changes and Financial Contagion on Stock Market Returns: Evidence from Five Asian Countries. Global Finance Journal, 19, 46-55.

Lintner, J. (1965). The Valuation of Risk Assets and the Selection of Risky Investments in Stock Portfolios and Capital Budgets. Review of Economics $\mathcal{E}$ Statistics, 47, 13-37.

Lui, D., Markov, S., \& Tamayo, A. (2012). Equity Analysts and the Market's Assessment of Risk. Journal of Accounting Research, 50, 1287-1317.

MacKinlay, G. A. (1997, March). Event Studies in Economics and Finance. Journal of Economic Literature, 35, 13-39.

Matthies, A. B. (2013). Empircal Research on Corporate Credit Ratings A Literature Review. 28.

May, A. D. (2010). The Impact of Bond Rating Changes on Corporate Bond Prices: New Evidence from Over-The-Counter Market. Journal of Banking \& Finance, 34, 2822-2836.

Miao, H., Ramchander, S., \& Wang, T. (2014). The Response of Bond Prices to Insurer Rating Changes. The Geneva Papers, 39, 389-413.

Mokoaleli-Mokoteli, T., \& Mongalo, B. (2017). The Impact of Corporate Credit Ratings Change on Stock Returns of Firms Listed on JSE Exchange. Proceedings of the European Conference on Management, Leadership \& Governance, 311-322.

Moody's Ratings Definintions. (2013). Retrieved April 6, 2013, from Moody's Web site: http://www.moodys.com/Pages/amr002002.aspx

Ng, H. G., \& McAleer, M. (2004). Recursive Modelling of Symmetric and Asymmetric Volatility in the Presence of Extreme Observations. International Journal of Forecasting, 20, 115-129.

Nordberg, D. (2011). Corporate Governance: Principles and Issues. London: Sage Publications.

Orlikowski, W. J., \& Baroudi, J. J. (1991). Studying Information Technology in Organizations: Research Approaches and Assumptions. Information Systems Research, 2, 1-28.

Pinches, G. E., \& Singleton, J. C. (1978). The Adjustment of Stock Prices to Bond Rating Changes. Journal of Finance, 33, 29-44.

Poornima, B. G., Umesh, N. P., \& Reddy, Y. V. (2015). The Impact of Changes in Credit Ratings on Stock Returns. The IUP Journal of Financial Risk Management, $12,52-67$.

Reserve Bank of New Zealand - Credit ratings of banks in NZ. (2016). Retrieved April 6, 2013, from Reserve Bank of New Zealand Web site: http://www.rbnz.govt.nz/ finstab/banking/4560094.html

Reuters. (2008). Reuters Guide to Credit Ratings, Scales and Terms. Retrieved 2017, from Reuters Web site: http://www.reuters.com/article/reuters-ratings-guideidUSRATINGS20080605

Sharpe, W. F. (1964). Capital Asset Prices: A Theory of Market Equilibrium Under Conditions of Risk. The Journal of Finance, 19, 425-442.

Standard \& Poor's Understanding Ratings. (2011). Retrieved April 6, 2013, from Standard \& Poor's Web site: http://img.en25.com/Web/StandardandPoors/ SP_CreditRatingsGuide.pdf 
Steiner, M., \& Heinke, V. G. (2001). Event Study Concerning International Bond Price Effects of Credit Rating Actions. International Journal of Finance and Economics, 6, 139-157.

Urguiza, F. B., Navarro, M. C., \& Trombetta, M. (2012). Disclosure Strategies and Cost of Capital. Managerial and Decision Economics, 33, 501-509.

Weinstein, M. I. (1977). The Effect of A Rating Change Announcement on Bond Price. Journal of Financial Economics, 5, 329-350.

Zhou, C. (2001). Credit Rating and Corporate Defaults. Journal of Fixed Income, 11, 30-40. 